\title{
Gas chromatography-mass spectrometry (GC-MS) analysis of ethyl acetate root bark extract of Strychnos innocua (Delile)
}

\author{
Hamisu Ibrahim ${ }^{1}$, Ahmed Jibrin Uttu² ${ }^{2^{*}}$, Muhammad Sani Sallau ${ }^{1}$ and Ogunkemi Risikat Agbeke lyun ${ }^{1}$
}

\begin{abstract}
Background: Majority of phytochemicals have been known to bear valuable therapeutic activities such as insecticidal, antibacterial, antifungal, anticonstipative, spasmolytic, antiplasmodial and antioxidant activities. Strychnos innocua is straight-stemmed tree belonging to the family Loganiaceae and can grow up to $18 \mathrm{~m}$ tall. The plant is used for various pharmacological purposes. The aim of this study was to determine the chemical composition of the ethyl acetate extract of root bark of S. innocua using GC-MS analysis. The root bark was collected, air-dried and then crushed to powder. Standard extraction method (maceration) was used to obtain the ethyl acetate extract. The GCMS was carried out on the extract using GC 7890B, MSD 5977A, Agilent Tech.

Results: Thirty-seven compounds were identified among which dibutyl benzene-1,2-dicarboxylate showed the highest peak area (31.03\%) and monomethyl pimelate showed the lowest peak area (0.39\%). The major compounds identified were cyclooctane (methoxymethoxy), 2,4-dimethylheptanedioic acid dimethyl ester, azelaic acid, 1,2-benzenedicarboxylic acid, bis(2-methylpropyl) ester, dibutyl benzene-1,2-dicarboxylate, butyl 8-methylnonyl benzene1,2-dicarboxylate, 9,15-octadecadienoic acid, methyl ester, cis-vaccenic acid, linoleic acid ethyl ester and ethyl oleate.
\end{abstract}

Conclusions: In conclusion, these phytoconstituents might be responsible for the medicinal efficacy of the root bark of $S$. innocua and can be used as a source therapeutic drug.

Keywords: GC-MS analysis, Strychnos innocua, Chemical composition, Loganiaceae

\section{Background}

About $80 \%$ of the world population depend on plantbased medicines as a source of primary health care in rural areas of both developing and developed countries, where modern medicines are mainly used [22]. Majority of phytochemicals have been known to bear valuable therapeutic activities such as insecticidal, antibacterial, antifungal, anticonstipative, spasmolytic, antiplasmodial and antioxidant activities [12]. Antiprotozoal activities of medicinal plants have also been reported $[24,26]$.

\footnotetext{
*Correspondence: jibuttu@yahoo.com

2 Department of Chemistry, Federal University Gashua, P. M. B. 1005,

Gashua, Yobe State, Nigeria

Full list of author information is available at the end of the article
}

The guidelines for the assessment of herbal medicines have once been issued by WHO, and these guidelines explained basic criteria for the evaluation of quality, safety and efficacy of herbal medicines with the goal of assisting national regulatory authorities, scientific organizations and manufacturers in assessing documentation, submissions and dossiers in respect of such products [25].

Strychnos innocua belongs to the family Loganiaceae and is often straight-stemmed tree growing up to $18 \mathrm{~m}$ tall. The trunk is usually $7-40 \mathrm{~cm}$ in diameter. The leaves are simple, alternate, leathery, subsessile or shortly petiolate, obovate, elliptic or oblong-elliptic, 4-15×2-9 cm, coriaceous; rounded marginate or subacute at the apex; widely to very narrowly cuneate or rarely rounded at the base; glabrous to pubescent beneath $[4,16]$. The root 
decoction is taken as a remedy for gonorrhoea, and the fresh roots are used to treat snakebite $[4,19]$.

$S$. innocua was reported to have rich alkaloid in its wood [5]. While studies on nutritional, antinutritional and chemical composition of fruits of S. innocua were also reported [1, 6, 20], antitrypanosomal activity of compounds from the leaves of Strychnos spinosa was reported $[9,10]$. The aim of this study was to determine the chemical composition of the ethyl acetate extract of root bark of S. innocua using GC-MS analysis. Ethyl acetate solvent was purposely used for extraction in this study due to its minimum toxicity and medium polarity in extracting both polar and nonpolar phytochemicals.

\section{Methods}

\subsection{Collection of plant sample}

The plant Strychnos innocua was harvested from forest of Soba Local Government Area, Kaduna State, Nigeria, and was identified by Mallam Namadi Sunusi, Department of Biological Sciences, Ahmadu Bello University, Zaria, Nigeria. A voucher specimen number was assigned (V/N 01884).

\subsection{Preparation of plant sample}

The root bark was rinsed, air-dried for 28 days and crushed to coarse powder.

\subsection{Extraction of plant sample}

The pulverized plant sample (2000 g) was separately macerated successively in n-hexane, ethyl acetate and methanol according to gradient polarity of the solvents. The maceration technique involved soaking the pulverize plant materials in an aspirator firstly with n-hexane (polarity $=0.009$ ) and allowing to stand at room temperature for a period of 3 days with frequent agitation. After exhaustive extraction with $n$-hexane, the procedure was repeated for ethyl acetate (polarity $=0.228$ ) and methanol (polarity $=0.762$ ). The ethyl acetate extract was then used for the gas chromatography-mass spectrometry (GCMS) analysis.

\subsection{GC-MS analysis}

The GC-MS analysis of ethyl acetate root bark extract of Strychnos innocua was performed using a GC 7890B, MSD 5977A, Agilent Tech and mass detector. Helium was the carrier gas at a flow rate of $1 \mathrm{ml} / \mathrm{min}$, and $1 \mu \mathrm{L}$ of the supernatant of the sample was injected into the GC. The GC oven temperature was programmed from $80^{\circ} \mathrm{C}$, with an increase of $15{ }^{\circ} \mathrm{C} / \mathrm{min}$, to $200{ }^{\circ} \mathrm{C}$ and then $5{ }^{\circ} \mathrm{C} /$ min to $280^{\circ} \mathrm{C}$, ending with a 5 -min isothermal at $280^{\circ} \mathrm{C}$. The ion source was set at $230^{\circ} \mathrm{C}$ and the ionization voltage at $70 \mathrm{eV}$.

\subsection{Identification of components}

Interpretation on GC-MS was conducted using the database of National Institute Standard and Technology (NIST). The mass spectrum of the unknown component was compared with the spectrum of the known components stored in the NIST library.

\section{Results}

The components identified are presented in Table 1, while the GC chromatogram is presented in Figs. 1 and 2.

\section{Discussion}

Species of plants in genus Strychnos are proving to be promising sources of compounds with important pharmacological properties. The GC-MS analysis of the ethyl acetate extract of root bark of Strychnos innocua resulted in the detection of 37 compounds that were identified among which dibutyl benzene-1,2-dicarboxylate showed the highest peak area $(31.03 \%)$ and monomethyl pimelate showed the lowest peak area $(0.39 \%)$. The major compounds identified were cyclooctane, (methoxymethoxy), 2,4-dimethylheptanedioic acid dimethyl ester, azelaic acid, 1,2-benzenedicarboxylic acid, bis(2-methylpropyl) ester, dibutyl benzene-1,2-dicarboxylate, butyl 8-methylnonyl benzene-1,2-dicarboxylate, 9,15-octadecadienoic acid, methyl ester, cis-vaccenic acid, linoleic acid ethyl ester and ethyl oleate.

$\mathrm{N}$-Methyl formamide possesses significant antitumor activities [7]. The azelaic acid is one of the fatty acid compounds that possess several medicinal properties such as antioxidative effects and anti-inflammatory and antimicrobial activities and used in the treatment of many skin problems $[15,18]$. Diisooctyl phthalate has been synthesized by catalysis of niobic acid [29]. Ethyl oleate is a fatty acid ester, is safe for oral ingestion [21] and is used as solvent for pharmaceutical drug preparations [17]. $\beta$-Elemenone was found in the extract of Curcuma longa, and the extract was found to possess antioxidant activity [23]. Linoleic acid ethyl ester has been reported to be effective in the treatment of infantile neuroaxonal dystrophyl [2]. 7-Hexadecenal has been identified among compounds that elicited electroantennogram responses from white-tailed bumblebee [28]. 4-Acetoxy-3-methoxystyrene was identified in the ethanolic extract of stem of Parthenium hysterophorus and possesses antimicrobial activity [13]. cis-Vaccenic acid was found as a prominent compound in Rhodopseudomonas capsulate and possesses antivirus activity [8]. Cyclooctane (methoxymethoxy) along other compounds was identified in Michelia champaca seed extract and possesses antimicrobial, antioxidant and anticancer properties [14]. 9-Octadecenoic acid methyl ester possesses antioxidant and anticancer 
Table 1 Phytoconstituents of the ethyl acetate root bark extract of S. innocua

\begin{tabular}{|c|c|c|c|c|c|}
\hline S/No. & RT & COMPOUND NAME & STRUCTURE / FORMULA & MW & $\begin{array}{l}\text { PEAK } \\
\text { AREA \% }\end{array}$ \\
\hline 1 & 1.188 & Formamide, $N$-methyl & $\mathrm{C}_{2} \mathrm{H}_{5} \mathrm{NO}$ & 59 & 0.89 \\
\hline 2 & 1.914 & 1-Methylcyclopropanemethanol & $\mathrm{C}_{5} \mathrm{H}_{10} \mathrm{O}$ & 86 & 0.67 \\
\hline 3 & 1.977 & 1-Methylcyclopropanemethanol & $\mathrm{C}_{5} \mathrm{H}_{10} \mathrm{O}$ & 86 & 0.50 \\
\hline 4 & 5.668 & 4-Acetoxy-3-methoxystyrene & $\mathrm{C}_{11} \mathrm{H}_{12} \mathrm{O}_{3}$ & 192 & 0.50 \\
\hline 5 & 5.943 & $\begin{array}{l}\text { 4-Fluoro-1-methyl-5- } \\
\text { carboxylic acid, ethyl(ester) }\end{array}$ & $\mathrm{C}_{7} \mathrm{H}_{9} \mathrm{FN}_{2} \mathrm{O}_{2}$ & 172 & 0.45 \\
\hline 6 & 6.131 & $\begin{array}{l}\text { 1-Methylene-2b- } \\
\text { hydroxymethyl-3,3-dimethyl- } \\
\text { 4b-(3-methylbut-2-enyl)- } \\
\text { cyclohexane }\end{array}$ & $\mathrm{C}_{15} \mathrm{H}_{26} \mathrm{O}$ & 222 & 0.45 \\
\hline 7 & 6.406 & $\begin{array}{l}\text { 2,4,6-Octatrien-1-ol, } \\
\text { dimethyl }\end{array}$ & $\mathrm{C}_{10} \mathrm{H}_{16} \mathrm{O}$ & 152 & 0.78 \\
\hline 8 & 6.601 & $\begin{array}{l}\text { 2,4-Dimethylheptanedioic acid } \\
\text { dimethyl ester }\end{array}$ & $\mathrm{C}_{31} \mathrm{C}^{-} \mathrm{H}_{20} \mathrm{O}_{4}$ & 216 & 0.39 \\
\hline 9 & 6.847 & $\begin{array}{l}\text { Cyclooctane, } \\
\text { (methoxymethoxy) }\end{array}$ & $\mathrm{C}_{10} \mathrm{H}_{20} \mathrm{O}_{2}$ & 172 & 3.74 \\
\hline 10 & 7.236 & Diethyl suberate & $\mathrm{C}_{12} \mathrm{H}_{22} \mathrm{O}_{4}$ & 230 & 1.00 \\
\hline 11 & 7.299 & $\begin{array}{l}\text { 2,4-Dimethylheptanedioic acid } \\
\text { dimethyl ester }\end{array}$ & $\mathrm{C}_{11} \mathrm{H}_{20} \mathrm{O}_{4} \mathrm{C}^{-}{ }^{\mathrm{O}}$ & 216 & 2.19 \\
\hline 12 & 7.396 & $\begin{array}{l}\text { 9-Dodecenoic acid, methyl } \\
\text { ester }\end{array}$ & $\begin{array}{c}\mathrm{H}_{3} \mathrm{C}^{\mathrm{O}} \prod_{\mathrm{O}} \\
\mathrm{C}_{13} \mathrm{H}_{24} \mathrm{O}_{2}\end{array}$ & 212 & 0.61 \\
\hline 13 & 7.436 & Monomethyl pimelate & $\mathrm{C}_{8} \mathrm{H}_{14} \mathrm{O}_{4}$ & 174 & 0.39 \\
\hline 14 & 7.510 & $\begin{array}{l}\text { 9-Dodecenoic acid, methyl } \\
\text { ester }\end{array}$ & $\mathrm{C}_{13} \mathrm{H}_{24} \mathrm{O}_{2}$ & 212 & 1.51 \\
\hline
\end{tabular}


Table 1 (continued)

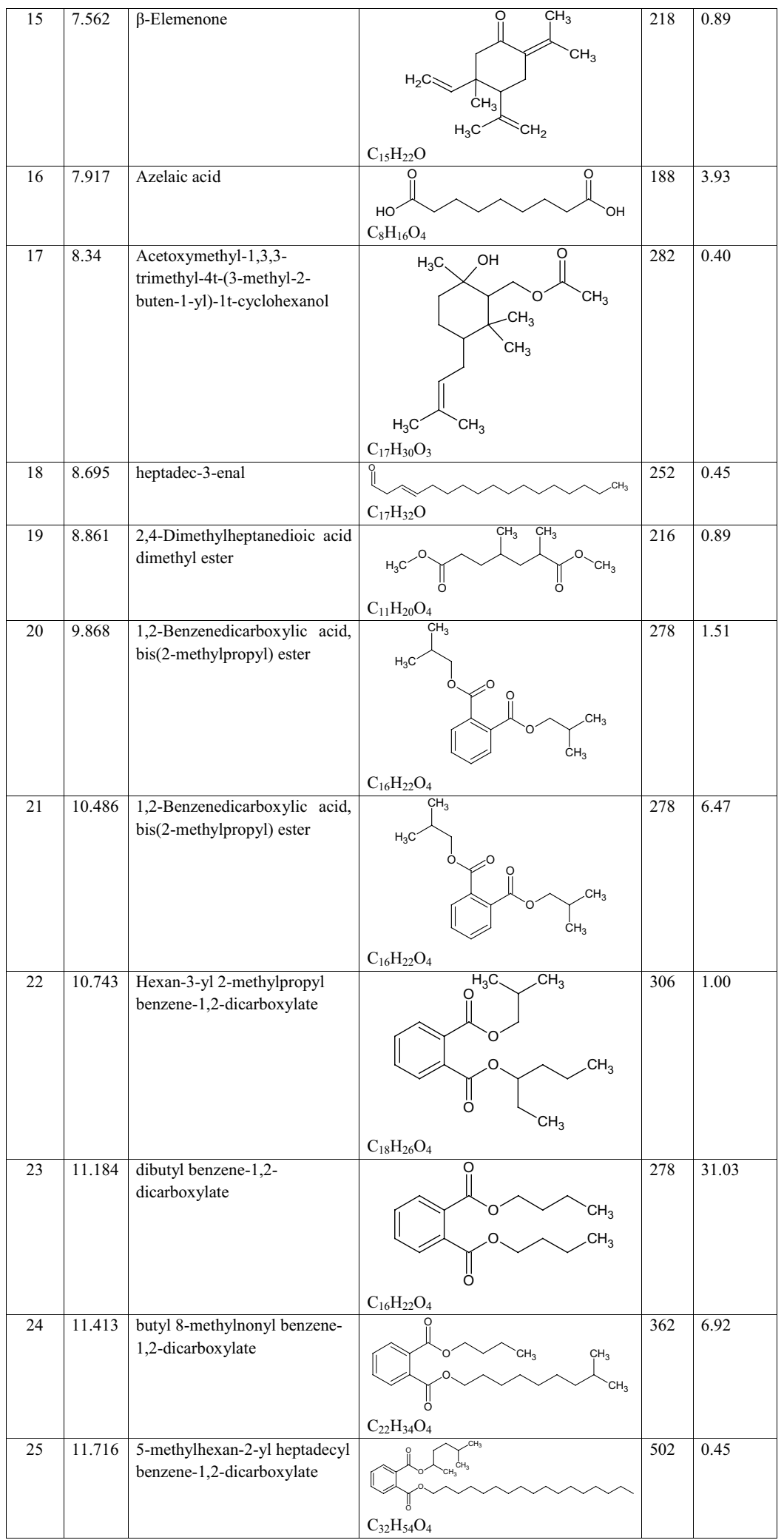


Table 1 (continued)

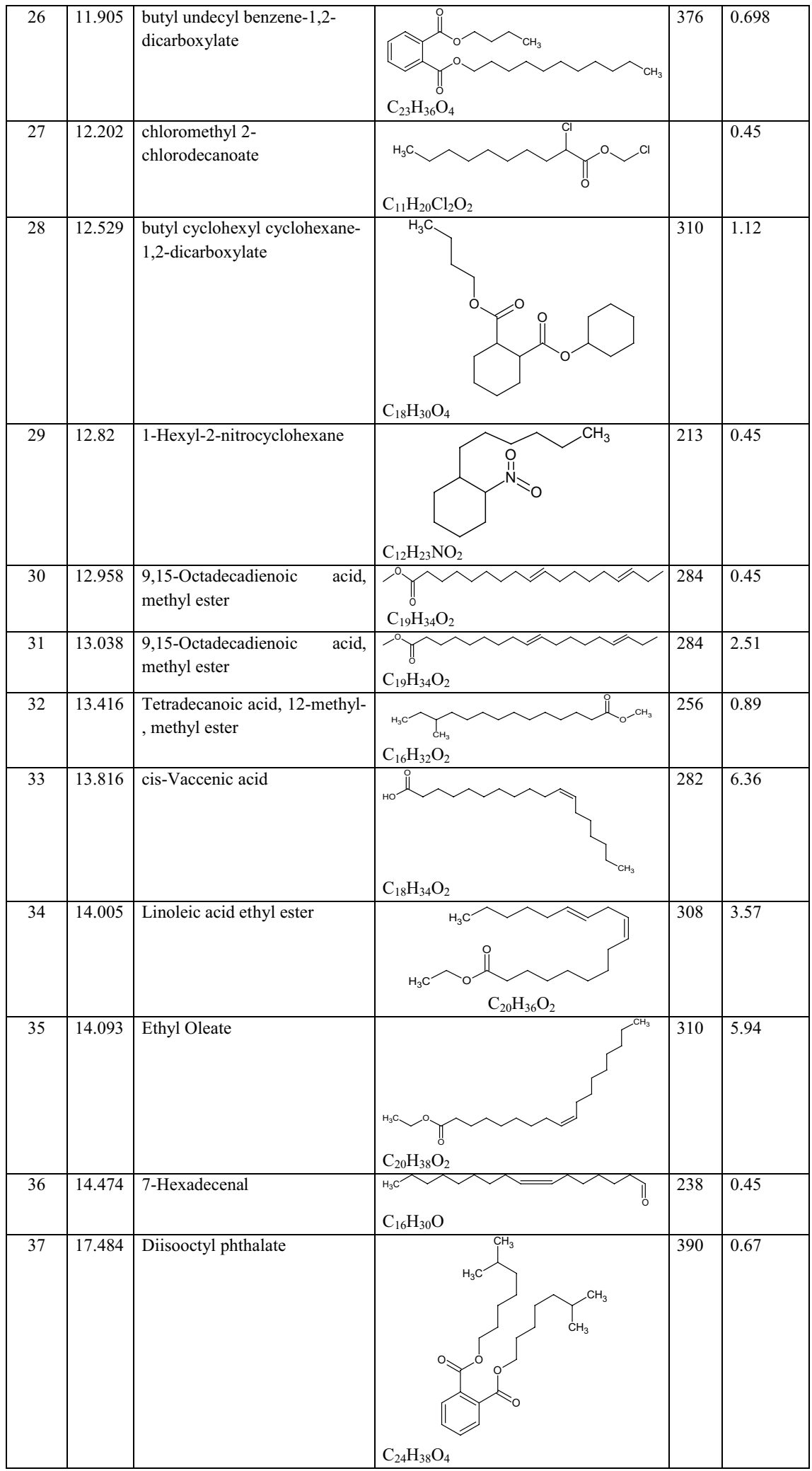




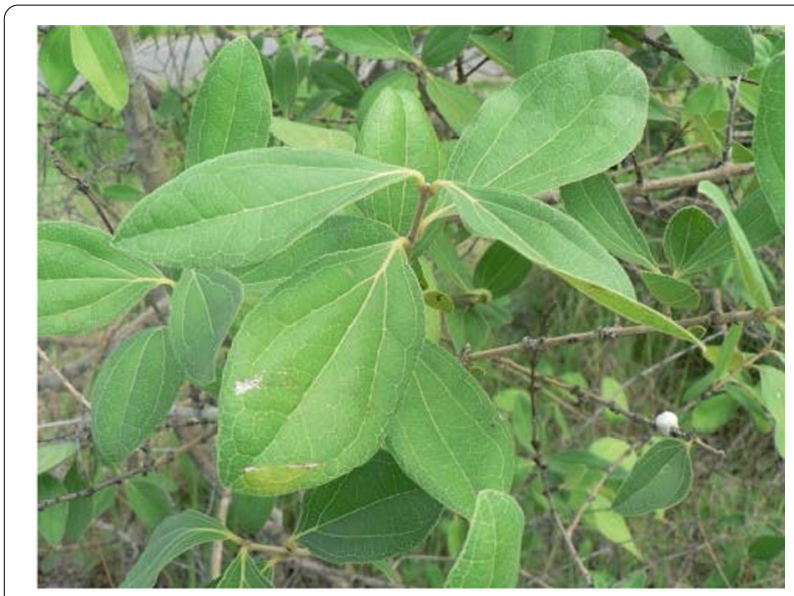

Fig. 1 Strychnos innocua, showing the leaves and branches activities [27]. 1-Hexyl-2-nitrocyclohexane was found in Phormidium autumnale extract and possesses antibacterial activities against Bacillus subtilis and Shigella sonnei [3]. Dibutyl benzene-1,2-dicarboxylate was identified among phytocompounds from the roots of Patrinia scabra and possesses cytotoxic activity [11]. The presence of various phytocompounds in the root of S. innocua might justify the use of the plant in folk medicine for the treatment of various ailments. However, isolation of individual components subjecting it to biological activity is recommended.

\section{Conclusions}

The present study investigated the phytoconstituents of $S$. innocua root bark that was harvested in the wild of Soba Local Government Area of Yobe State. Nigeria. Thirtyseven compounds were identified (GC-MS analysis) in which bioactivities and or industrial applications of some

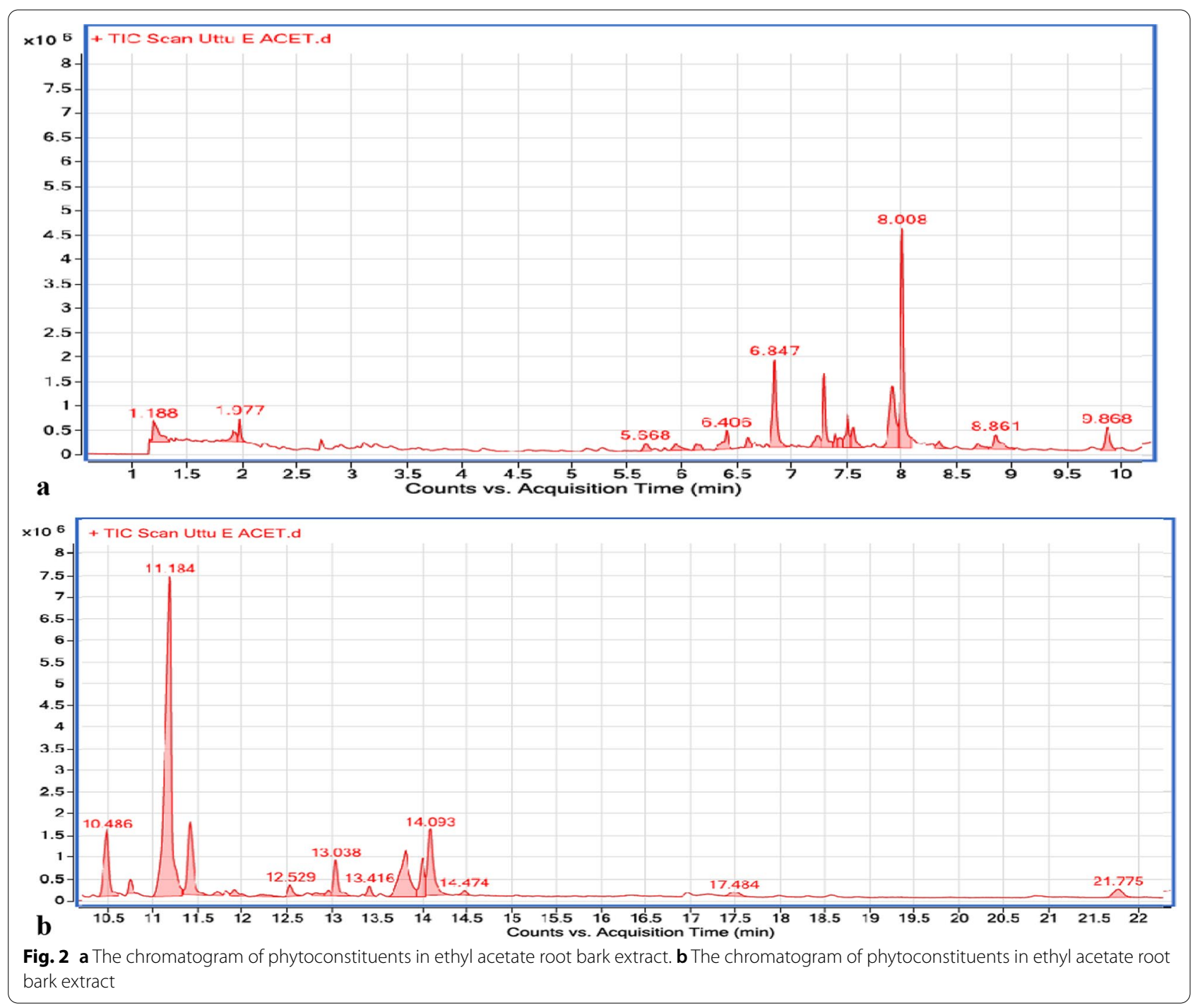


of the compounds have been reported in various studies. The data obtained from the GC-MS analysis might suggest that the root of $S$. innocua may be a good source of therapeutic drugs.

\section{Abbreviations}

GC-MS: Gas chromatography-mass spectrometry; V/N: Voucher number; RPM: Rotation per minutes; $\mu \mathrm{L}$ : Microliter; RT: Retention time; MW: Molecular weight; $\%$ : Percentage.

\section{Acknowledgements}

The authors are grateful to Mallam Samaila Mustapha for providing the plant We are also thankful to Mallam Idris of Chemistry Laboratory, Yobe State University, Damaturu, for his valuable technical assistance in GC-MS analysis.

\section{Authors' contributions}

$\mathrm{HI}$ gave all the procedure/reviewed the manuscript. ORI gave the procedure for GC-MS analysis/reviewed the manuscript. AJU carried out the experiments/wrote the manuscript. MSS assisted in carrying out the experiments/ reviewed the manuscript. All authors read and approved the final manuscript.

\section{Funding}

Not applicable.

\section{Availability of data and materials}

Not applicable.

\section{Declarations}

Ethics approval and consent to participate

Not applicable.

\section{Consent for publication}

Not applicable.

\section{Competing interests}

The authors declare no competing interests.

\section{Author details}

${ }^{1}$ Department of Chemistry, Ahmadu Bello University, Zaria, Nigeria. ${ }^{2}$ Department of Chemistry, Federal University Gashua, P. M. B. 1005, Gashua, Yobe State, Nigeria.

Received: 20 August 2021 Accepted: 4 October 2021

Published online: 16 October 2021

\section{References}

1. Abdulmumin U et al (2017) Nutritional and anti-nutritional composition of monkey orange (Strychnos innocua Del) fruit seeds grown in Zuru, Nigeria. Afr J Food Sci Technol 8(4):56-62

2. Adams D, Midel MJ, Dastgir J, Flora C, Molinari RJ, Heerinckx F, Endemann S, Atwal P, Milner P, Shchpinor MS (2020) Treatment of infantile neuroaxonal dystrophy with RT001: a di-deuterated ethyl ester of linoleic acid: report of two cases. JIMD Rep 54(1):54-60

3. Al-Wathnani H, Ismet A, Tahmaz RR, Al-Dayel TH, Bakir MA (2012) Bioactivity of natural compounds isolated from cyanobacteria and green algae against human pathogenic bacteria and yeast. J Med Plants Res 6(18):3425-3433. https://doi.org/10.5897/JMPR11.1746

4. Anonymous (2007) Ecocrop: Stychnos innocua. Food and agriculture organization of the UN. Retrieved from http://ecocrop.fao.org/ecocr op/srv/en/cropView?id=1013

5. Asuzu CU, Nwosu MO (2020) Studies of the wood of some Nigeria alkaloid-rich Strychnos species. J Hortic For 12(2):57-62
6. Bello MO, Olawore NO, Falade OS, Adewusi SRA (2007) Studies on the chemical compositions and AntiNutrients of some lesser known fruits. Biochem Indian J 1(2):88-97

7. Gescher A, Gibson NW, Hickman JA, Langdon SP, Ross D, Atassi G (1982) N-methylformamide: antitumour activity and metabolism in mice. Br J Cancer 45(6):843-850

8. Hirotani H, Ohigashi M, Kobayashi K, Koshimizu K, Takahashi E (1991) Inactivation of T5 phage by cis-vaccenic acid, an antivirus substance from Rhodopseudomonas capsulate, and by unsaturated fatty acids and related alcohols. FEMS Microbiol Lett 77(1):13-17. https://doi.org/10. 1111/j.1574-6968.1991.tb04314.x

9. Hoet S, Pieters L, Muccioli GG, Habib-Jiwan J, Opperdoes FR, QuetinLeclercq J (2007) Antitrypanosomal activity of triterpenoids and sterols from the leaves of Strychnos spinosa and related compounds. J Nat Prod 70:1360-1363. https://doi.org/10.1021/np070038q

10. Hoet S, Stevigny C, Herent M, Quetin-Leclercq J (2006) Antitrypanosomal compounds from the leaf essential oil of Strychnos spinosa. Planta Med 72:480-482. https://doi.org/10.1055/s-2005-916255

11. Hongxiang S, Cuirong S, Yuanjian P (2005) Cytotoxic activity and constituents of the volatile oil from the roots of Patrinia scabra Bunge. Chem Biodivers 2(10):1351-1357. https://doi.org/10.1002/cbdv.20059 0107

12. Igbal H, Moneebur RK, Riazullah ZM, Naeem KFA, Zahoor U (2011) Phytochemical screening and antimicrobial activities of selected medicinal plants of Khyber Pakhtunkhwa, Pakistan. Afr J Pharm Pharmacol 5(6):746-750

13. Krishnaveni M, Kalaivani M, Banu CR, Kumari GK (2015) GC-MS/MS study of Parthenium hysterophorus $L(N$. Am) stem, antimicrobial activity. Res J Pharmacy Technol 8(5):517-519

14. Lee SW, Wendy W, Julius YFS, Desy FS (2011) Characterization of antimicrobial, antioxidant, anticancer properties and chemical composition of Michelia champaca seed and flower extracts. Stamford J Pharmaceut Sci 4(1):19-24. https://doi.org/10.3329/sjps.v4i1.8862

15. Leeming JP et al (1986) The in vitro antimicrobial effect of azelaic acid. Br J Dermatol 115(5):551-556

16. Orwa CA, Mutua KR, Jamnadass R, Anthony S (2009) Agroforestree database: a tree reference and selection guide version 4.0. Retrieved from http://www.worldagroforestry.org/sites/treedbs/treedatabases. asp

17. Ory SJ et al (1993) The effect of a biodegradable contraceptive capsule (capronor) containing levonogetrel on gonadotropin, estrogen, and progesterone levels. Am J Obstet Gyneacol 145(5):600-605

18. Paula D, Anna P, Magdalena N, Natalia T (2018) The use of azelaic acid in selected dermatological disorders. Med Rodz 21(4):307-314

19. Ruffo CK, Birnie A, Tengnas B (2002) Edible wild plants of Tanzania. Regional Land Management Unit; Nairobi

20. Ruth TN, Anita RL, Loveness KN, Vincenzo F, Ruud V (2017) Local processing and nutritional composition of indigenous fruits: the case of monkey orange (Strychnos spp.) from Southern Africa. Food Rev Int 33(2):123-142

21 Saghir M (1997) Rapid in vivo hydrolysis of fatty acid ethyl esters, toxic nonoxidative ethanol metabolites. Am J Physiol 273:184-190

22. Seth SD, Sharma B (2004) Medicinal plants in India. Indian J Med Res 120:9-11

23. Singh G, Kapoor IPS, Singh P, Carola S et al (2010) Comparative study of chemical composition and antioxidant activity of fresh and dry rhizomes of turmeric (Curcuma longa Linn.). Food Chem Toxicol 48(4):1026-1031. https://doi.org/10.1016/j.fct.2010.01.015

24. Vasquez-Ocmin P, Cojean S, Rengifo C, Suyyagh-Albouz S, Guerra CAA, Pomel S, Maciuk A (2017) Antiprotozoal activity of medicinal plants used by lquitos-Nauta road communities in Loreto (Peru). J Ethnopharmacol. https://doi.org/10.1016/j.jep.2017.08.039

25. WHO (1996) Annex II. Guidelines for the assessment of herbal medicines (WHO Technical Report Series No. 863), Geneva

26. Yi Y, Lu C, Hu X, Ling F, Wang G (2012) Antiprotozoal activity of medicinal plants against /chthyophthirius multifilis in goldfish (Carassius auratus). Parasitol Res 111:1771-1778. https://doi.org/10.1007/ s00436-012-3022-7

27. Yu FR, Lian XZ, Guo HY, McGuire PM, Li RD, Wang R, Yu FH (2005) Isolation and characterization of methyl esters and derivatives from 
Euphorbia kansui (Euphorbiaceae) and their inhibitory effects on the human SGC-7901 cells. J Pharm Pharm Sci 8:528-535

28. Zacek P, Blanka K, Sobotnik J, Hovorka O, Ptacek V, Coppee A, Verheggen F, Irena $V$ (2009) Comparison of age-dependent quantitative changes in the male labial gland secretion of Bombus terrestris and Bombus lucorum. J Chem Ecol 35(6):698-705

29. Zhikun W, Juran L, Jian G, Shanxin Y (2000) Niobic acid catalysed synthesis of diisooctyl phthalate. Adv Fine Petrochem 7:18-19

\section{Publisher's Note}

Springer Nature remains neutral with regard to jurisdictional claims in published maps and institutional affiliations.

\section{Submit your manuscript to a SpringerOpen ${ }^{\circ}$ journal and benefit from:}

- Convenient online submission

- Rigorous peer review

- Open access: articles freely available online

- High visibility within the field

- Retaining the copyright to your article

Submit your next manuscript at $\boldsymbol{\nabla}$ springeropen.com 